\section{Arbeidsmedisin på legevakten}

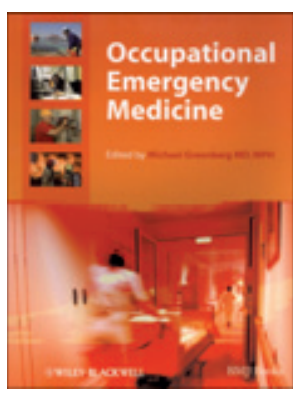

Michael Greenberg, red. Occupational emergency medicine

280 s, tab, ill. Chichester: Wiley-Blackwell, 2011. Pris GBP 45

ISBN 978-1-4051-8071-9

Temaet som tas opp, har jeg ikke sett behandlet tidligere. Man skulle tro at arbeidsmedisin, et forebyggende fag med vekt på langsiktig gruppetilnærming, og akuttmedisin med vekt på rask behandling av individer i krise, sto så langt fra hverandre et en lærebok om temaet var lite aktuell, og det første kapitlet brukes til å begrunne hvorfor boken trengs. Den er nok mindre aktuell i Norge enn i USA hvor den er skrevet, stort sett av akuttmedisinere fra Philadelphia. USA har verken folketrygd eller fastleger, og når $15 \%$ av befolkningen mangler helseforsikring, blir kanskje legevakten det første møtestedet mellom mange syke og legen. De arbeidsmedisinske oppgavene for akuttmedisinere som det blir pekt på, hører heller inn under fastlegenes oppgaver her hos oss.

Budskapet er at det å overse arbeidsmiljøets betydning, kan ha store negative konsekvenser for den enkelte pasients helse og økonomi, og at det forspiller muligheter for forebyggende arbeid blant pasientenes arbeidskolleger og andre i tilsvarende arbeidssituasjon. Viktigheten av å ta opp en yrkesanamnese av alle yrkesaktive pasienter blir presisert.

Uforholdsmessig mye plass blir brukt på behandling av tilfeller som bare tilfeldigvis er yrkesbetinget, som traumer og infeksjoner og noe er heller kuriøst, som behandlingen av pest og rabies. Sykdommer som skyldes eksponeringer som i all hovedsak finnes på arbeidsplasser, kunne fått mer plass. Et hederlig unntak er kapitler om arbeidsbetingede lungesykdommer som jeg lærte mye av. Noen yrker har fătt egne kapitler, politifolk og vektere, brannfolk, helsepersonell i og utenfor sykehus, sjåfører og kunstnere. Et kapittel handler om katastrofer, et annet om utredning av stemmeforstyrrelser. Det faglige nivået er varierende, fra en opplysning om at øyet ligger i noe som heter orbita, til cellebiologiske hendelser ved allergisk alveolitt.

Noe plass går med til overlapping, f.eks. refererer nesten hvert kapittel til trygde- og forsikringsmessige rettigheter i USA (som ikke likner mye på det vi har her), og noen forgiftninger og infeksjoner er behandler flere ganger. Språket er gjennomgående bra, ukomplisert, men presist.

Boken er for ujevn i kvalitet og for mye preget av forholdene der den er skrevet, til at jeg vil anbefale den for norske leger. De som måtte være nysgjerrige på faget arbeidsmedisin vil ha større glede av en dansk bok (1).

\section{Håkon Lasse Leira}

Arbeidsmedisinsk avdeling

St Olavs hospital

\footnotetext{
Litteratur

1. Sigsgaard T, Bonde JP, Rasmussen K, red. Miljø- og arbejdsmedicin. 3. utg. København: FADL's Forlag, 2010.
}

\section{Kliniske kjennetegn i oftalmologi}

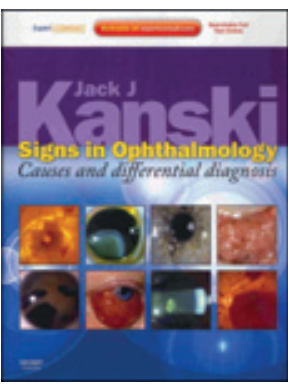

\author{
Jack J. Kanski \\ Signs in ophthalmology
}

Causes and differential diagnosis. 432 s, tab, ill. Philadelphia, PA: Mosby Elsevier, 2010.

Pris USD 149

ISBN 978-0-7234-3548-8

Jack J. Kanskis bøker er velkjente oppslagsverk blant dagens øyeleger. Målgruppen for denne utgaven, som er en illustrert oversikt over kliniske tegn og karakteristiske funn ved ulike øyesykdommer, er leger under utdanning i øyesykdommer. Særlig i den første delen av utdanningen, hvor man skal tilegne seg mange nye og ukjente faguttrykk og lære å finne ofte subtile sykdomskjennetegn, kan denne boken være til god hjelp. Men også andre leger som møter pasienter med øyesymptomer og har behov for å slå opp i et oppslagsverk med bilder og med kort beskrivelse av de klassiske kjennetegnene, vil kunne ha glede av den. Bilder av de mer sjeldne tilstander gjør at den også kan være til nytte for den erfarne øyespesialist.

Jeg er enig med forfatteren $i$ at diagnostikken av øyesykdommer i høy grad baserer seg på korrekt observasjon og tolking av kliniske tegn. Disse presenteres som et opplagsverk med fotografisk fremstilling av ulike sykdomstegn med kortfattet tekst. Der det er hensiktmessig følger en passende tabellmessig oversikt over sykdommer som kan ha disse spesifikke kjennetegn. I tillegg gjør forfatteren oppmerksom på mulige ledsagende funn («look for»), som kan være av stor betydning for å stille den riktige diagnosen. Flere faguttrykk presenteres med en kort og presis definisjon, og der det passer nevnes mulige differensialdiagnoser. Håndillustrasjoner viser avvikende pupillære reaksjoner, mens en serie med bilder demonstrerer klassiske funn ved unormale øyebevegelser og posisjon av øynene i forskjellige blikkretninger. Avslutningsvis presenteres kliniske tegn ved generelle sykdommer som ofte ledsages av øyesykdom.

Kvaliteten på bildene er god, men ikke fremragende. På de fleste er det lett å se detaljene som bildene skal illustrere, selv om fargekvaliteten er noe dårligere enn ønskelig. Det er enkelt å slå opp i boken, stoffet er oversiktlig med fargerik tekst og ikke overlesset layout. Jeg har stort sett funnet det jeg ønsket å finne av de klassiske kjennetegn.

Med papirutgaven følger også adresse til nettutgaven som det er lett å få tilgang til. Også her viste min dataskjerm noe lavere kontrastkvalitet enn jeg kunne ønske meg. Ifølge forfatteren kan bildene brukes i undervisning. Det er et verdifullt tilleggspoeng, fordi det ofte er vanskelig å finne gode bilder som illustrerer nettopp de kjennetegn som er karakteristiske for den øyesykdom man vil lære om.

Alt $i$ alt synes jeg at boken svarer til forventningen om en rask og oversiktlig orientering om viktige kliniske kjennetegn i oftalmologien, hvor andre mer omfattende oppslagsverk selvfølgelig må benyttes videre i diagnostikk og behandling av øyesykdommer.

\section{Anna Midelfart}

Institutt for nevromedisin

Norges teknisk-naturvitenskapelige universitet 